\title{
LUT
}

University

\section{Understand what your maintenance service partners value}

\begin{abstract}
Ali-Marttila Maaren, Marttonen-Arola Salla, Kärri Timo, Pekkarinen Olli, Saunila Minna
\end{abstract}

This is a Post-print version of a publication

published by Emerald Publishing

in Journal of Quality in Maintenance Engineering

DOI: $10.1108 / J Q M E-08-2016-0035$

Copyright of the original publication: (c) 2017, Emerald Publishing

Please cite the publication as follows:

Ali-Marttila, M., Marttonen-Arola, S., Kärri, T., Pekkarinen, O., Saunila, M. (2017). Understand what your maintenance service partners value. Journal of Quality in Maintenance Engineering, vol. 23, issue 2. pp. 144-164. DOI: 10.1108/JQME-08-2016-0035

This is a parallel published version of an original publication. This version can differ from the original published article. 


\title{
Understand what your maintenance service partners value
}

\begin{abstract}
Purpose - The study aims to identify what is currently valued in maintenance services. The study first conceptualizes the value construct through an examination of its elements including both financial and non-financial elements, and secondly provides insight into its actors' (i.e. customer companies, service providers, equipment providers) attitudes towards value creation.

Design/methodology/approach - This study uses data collected from maintenance service professionals by an online-survey. First an explorative factor analysis was conducted to examine the value construct. After this cluster analysis was conducted to define the actors.
\end{abstract}

Findings - The empirical findings suggest seven main elements that capture the maintenance service value: relationship synergies, reliability of the service partner, development, availability, service solutions and problem solving ability, EHSQ (environment, health, safety and quality) and adaptability to suit different situations. Further analysis revealed that the actors can be divided into three main strategy types: basic, quality and collaboration oriented partners.

Originality/value - In previous studies the comprehensive nature of maintenance service value has received less attention and the literature has focused more on the technical and financial aspects. This paper provides a new conceptualization of the value creating elements including also non-financial elements and offers an integrated measure for the actors to identify the comprehensive value construct around maintenance services. In addition, the findings show that the actors in the field still have very varying strategies when considering value creation. Communication and mutual understanding of the value creating elements is important so that right services are carried out and developed with the right partners.

Keywords Collaboration, Value creation, Relationship value, Maintenance services, Value element

Paper type Research paper

\section{Introduction}

Maintenance management has moved from a cost-centric view towards a more value-centric perspective where the service is not only considered as a cost factor but it can also create additional value (Liyanage and Kumar, 2003; Parida and Kumar, 2006; Pintelon and ParodiHerz, 2008). In addition, the maintenance field is constantly evolving as in-house maintenance organizations have partly moved towards partnerships in different company networks where the actors (i.e. customer companies, service providers and equipment providers) operate (Ahonen et al., 2010; Riis et al., 2007). The service aspect is now a common part of maintenance. In order to improve the competitiveness of the service relationships, it is essential for the organizations to gain mutual understanding of what the value creating elements in the service network are so that benefits like performance efficiency and reliability can be achieved (e.g. Barry and Terry, 2008; Lapierre, 2000; Ulaga, 2003). Mutual understanding helps to avoid disagreements, lack of quality and sub-optimization between service partners and instead highlight the positive effects of service collaboration so that all parties can benefit from the service relationship. 
Maintenance service value constitutes of a diverse range of different elements and it is also very maintenance case specific which makes the identification of the overall value complex (e.g. Toossi et al., 2013). Despite the increasing recognition of comprehensive maintenance value the relationships are still often oriented around price. Often this results in short-term decisions which can be quite problematic in maintenance as many of the benefits are created over long-term. Especially for the more complex offerings the relationship learning enabled over long-term is an important part of value co-creation (Kohtamäki and Partanen, 2016). Systematic ways to understand and measure what the maintenance service value for each actor is are needed as this would help the building of sustainable and successful relationships (Ahonen et al., 2010; Lapierre, 2000; Panesar and Markeset, 2008; Reinartz and Ulaga, 2008). To capture the comprehensive value of maintenance services, both financial (e.g. cost savings, price) and non-financial (e.g. trained labor, willingness to cooperate, reputation, safety) elements need to be viewed at (Liyanage and Kumar, 2003; Ojanen et al., 2012A; Toossi et al., 2013).

This research focuses on the comprehensive service value of maintenance which has been rather scarce in earlier studies as the literature has focused previously more on the technical and financial aspects. This paper aims to clarify the nature of maintenance service value first by an examination of its elements, and secondly by providing insights into different value creation strategies of the actors.

On the one hand, the research supports the multidimensional and complex nature of maintenance service value as the empirical findings show that value creation is characterized through multiple elements. On the other hand, the findings show that the actors in the field are very heterogeneous when considering the attitudes towards value. Others do not emphasize any particular elements and keep the service relationship more on the transactional side as others emphasize more the relational aspects and non-financial elements of the service. Therefore, when designing and evaluating value creating maintenance services academics and managers should keep in mind the heterogeneity of the actors and possible differences in evaluation criteria. When aiming towards more collaborative relationships also the non-financial elements have to be considered and measured for. Communication is key in developing right offerings with the right partners.

The paper is structured as follows. In Section 2 the value creation is described in the context of maintenance services. Next (Section 3) the methods and data used in the study are presented. The results are reported in Section 4. The overall results managerial implications and future research are discussed in Section 5 and final conclusions in Section 6.

\section{Value creation in maintenance services}

\section{Maintenance focus moving from cost-centric to value-centric}

Maintenance management has had a paradigm shift from being viewed as a cost to being looked as a service that can create value. In the early 1900s maintenance was considered as a "necessary evil" that "costs what it costs". Technologies were not that advanced yet and failures just occurred randomly. After the 1950s technologies advanced and methods like preventive maintenance and condition monitoring were introduced. This changed the cost-centric view to "it can be planned and controlled" and maintenance became an important support function. Value thinking within companies has emerged and maintenance is treated more and more as strategic issue instead of purely a technical one (Pintelon and Parodi-Herz, 2008). As Rosqvist et al. (2009) suggest in their Value Driven Maintenance Planning model the maintenance objectives should drive from the strategic objectives and KPI's of the company. Now 
maintenance can be treated as an integral part of the business process and e.g. Liyanage and Kumar (2003) suggest that it can create additional value to companies. (Parida and Kumar, 2006)

However, often for companies the optimization of maintenance still means the minimizing of cost in the short term instead of maximizing the value through long term objectives and continuous improvement (Marais and Saleh, 2008; Murthy et al., 2015). Marais and Saleh (2008) argue that by only focusing on the cost-centric views an important dimension of maintenance, value, is forgotten and this can lead to sub-optimal maintenance strategies. Therefore both sides: assessment of the value of maintenance and an assessment of the costs of maintenance should be involved when determining a maintenance strategy (Marais and Saleh ibid.). A multidisciplinary view involving e.g. finance, marketing and operations within companies should be included to guide the operations in a comprehensive and value-optimized way (Marais and Saleh, 2008). Also Liyanage and Kumar (2003) are promoting the valuebased view to maintenance. A more comprehensive view and overall results should be looked at than focusing only on cost cutting and controlling operational expenses (which has led to companies to optimize maintenance as a cost center). Pure cost-centric views can lead to short sighted decisions that can add to the total cost. This happened for example as an offshore oil production platform P-36 sunk due to too ambitious cost saving efforts (Liyanage and Kumar, 2003). The businesses should extend their understanding beyond the financial and cost-centric view and elaborate to the value-added processes (Liyanage and Kumar ibid; Parida and Kumar, 2006).

By moving from the cost-centric view towards more value-centric views also brings the focus on the long term development aspects. Supporting the long term development and profitability of an organization is one of the key functions of maintenance (Al-Sultan and Duffuaa, 1995; Parida and Kumar, 2006). Maintenance is also a field that effects all three dimensions of sustainability, namely, economic, environmental, and social and is thus also influencing the corporate level sustainability by creating/destroying (if organized badly) long-term shareholder value (Lo, 2010). Therefore it is important to not look at maintenance only as a plant based cost center but from a long term business-oriented view (Liyanage and Kumar, 2003; Panesar and Markeset, 2008; Pintelon and Parodi-Herz, 2008). This way also the long term benefits of appropriate maintenance (e.g. quality of work, availability, safety incidents) can be seen and the value creation optimized comprehensively in the long run.

\section{Maintenance outsourcing and service relationships}

Maintenance operations are often at least partly outsourced, which emphasizes the role of the inter-organizational relationship. The nature of the business has changed; maintenance service suppliers are now an important part of the business landscape. Also equipment providers are keen to provide added value through services besides to traditional equipment exchange as they can reach more steady cash flows and better customer satisfaction with the added services (e.g. Johansson and Olhager, 2004; Kindström and Kowalkowski, 2009). In-house maintenance organizations have shifted towards partnerships in different company networks where the customer, service providers and equipment providers operate (Ahonen et al. 2010; Riis et al., 2007).

From the customer's point of view increasingly complex assets have grown the knowledge intensity of operations making the maintaining of special know-how, resources and required skills in-house not always profitable. This has attracted specialization in the service provider field and outsourcing is now a sought-after option in many cases (e.g. Al-Turki, 2011). Persona et al. (2007) has classified possible benefits of outsourcing as follows: business improvement 
through cost reduction and efficiency, improving performance of existing lines of business and focus on core functions (technology-related assets). Also flexibility and access to new markets, skills and latest technology (Lorenzoni and Lipparini, 1999; Kremic et al., 2006) as well as sharing the risks, resources, knowledge and R\&D development (e.g. McDonough et al., 2006) can motivate the partnerships in maintenance. Stremersch et al. (2001) add integrated solutions and full service concepts to the list behind motivations to purchase the maintenance services from external service or equipment providers.

Outsourcing and service relationships can also have a positive effect on company growth and innovativeness when the ability to integrate the company's own knowledge with the partnering outside company's successes. It should be remembered that complex company networks engage in more than just transactions around services, goods and revenue (Allee, 2000). Also knowledge value and intangible value or benefits are shared (Grönroos and Helle, 2010). Studies suggest that collaborative agreements and partnerships can have positive effects on revenue and profit in the manufacturing industry (e.g. Stuart, 2000). Even though versatile benefits have been acknowledged in service relationships, for many companies the decisions related to outsourcing of maintenance operations and their management is still made on possible short term cost savings (Murthy et. al, 2015). The discussion focuses on the transactions around the services and goods instead of improving the processes in long term and creating mutual development objectives.

If the outsourcing process is poorly managed, the results of outsourcing are not always positive as also new risks are included (Campbell, 1995; Kremic et al. 2006). Often benefits are overemphasized in the planning phase and the savings remain unrealized and in worst case scenarios result in increased overall cost. Other risks are for example: issues relating to personnel and their motivation and morale, unsatisfied customers, power shift and dependence on a supplier, knowledge and competence loss (Bertolini et al., 2004; Kremic et al., 2006). In addition Campbell (1995) lists as one concern the potential loss of cross-functional communication which can lead to less flexible processes. With more and more complex technologies one part of the communication is efficient data management. This is often ignored in the contracts which can cause serious problems in the information flow and management of operations between the different parties of outsourced maintenance (Murthy et al., 2015).

\section{Value creating service relationships}

Value creation has two sides: value created for the customer and value created for the company offering the service (Gupta and Lehmann, 2005). This means that in a business relationship value creation is reciprocal and the services offered work as a mediating factor in the process where the parties involved should achieve value (Ballantyne and Varley, 2006; Grönroos, 2011; Grönroos and Ravald, 2009). When considering business-to-business services in most cases the value will be interactional and dependent on issues like performance and quality, and also relationship related aspects like e.g. administrative routines and communication (La Rocca and Snehota, 2014; Lindgreen and Wynstra, 2005; Vargo and Lusch, 2008). Value is related to the solutions created at different relationship facets and therefore value is created in interaction between the customer and supplier rather than unilaterally by one party (Ballantyne and Varey, 2006; La Rocca and Snehota, 2014; Tuli et al., 2007).

The nature of service relationships are varying and can be considered to form a continuum on a range from transactional to relational exchange and full collaboration (e.g. Axelsson and Wynstra, 2002; Day, 2000; Lindgreen et al., 2012; Penttinen and Palmer, 2006). Table 1 lists the recognizable features of the end points of the continuum. 
Ali-Marttila, M., Marttonen-Arola, S., Kärri, T., Pekkarinen, O., \& Saunila, M. (2017). Understand what your maintenance service partners value. Journal of quality in maintenance engineering, 23(2), 144-164.

Table 1. Transactional versus relational exchange (adapted from Axelsson and Wynstra, 2002 and Lindgreen et al., 2012)

\begin{tabular}{|c|c|c|}
\hline Perspective & Transactional approach & Relational approach \\
\hline Competition & Many alternatives & One or few alternatives \\
\hline Tactical focus & $\begin{array}{l}\text { Every deal is a new business, no one } \\
\text { should benefit from past } \\
\text { performances }\end{array}$ & $\begin{array}{l}\text { A deal is part of a relationship and the } \\
\text { relationship is part of a network context }\end{array}$ \\
\hline Relationship attitude & $\begin{array}{l}\text { Exploit the potential of competition; } \\
\text { anonymous and efficient market }\end{array}$ & $\begin{array}{l}\text { Exploit the potential of cooperation; } \\
\text { numerous market networks }\end{array}$ \\
\hline Time horizon & $\begin{array}{l}\text { Short term; arm's length, avoid } \\
\text { coming to close }\end{array}$ & $\begin{array}{l}\text { Long term with tough demands and joint } \\
\text { development }\end{array}$ \\
\hline Renewal & $\begin{array}{l}\text { Effective renewal through partner } \\
\text { changes, choose the most efficient } \\
\text { supplier at any time }\end{array}$ & $\begin{array}{l}\text { Effective renewal through collaboration } \\
\text { and teamwork, combine resources and } \\
\text { knowledge }\end{array}$ \\
\hline Services & $\begin{array}{l}\text { Buying "products". } \\
\text { augment the core product }\end{array}$ & $\begin{array}{l}\text { Buying "capabilities". Services are basis } \\
\text { for differentiation. }\end{array}$ \\
\hline Orientation & $\begin{array}{l}\text { Price orientation, strong in achieving } \\
\text { favorable prices in well-specified } \\
\text { products }\end{array}$ & $\begin{array}{l}\text { Cost and value orientation, strong in } \\
\text { achieving low total costs of supply and } \\
\text { developing new values }\end{array}$ \\
\hline
\end{tabular}

Together with the nature of the relationship and related interactions also the service offering changes (Oliva and Kallenberg, 2003). The completeness of a service offering can also be measured on a continuum from less complete (e.g. basic components) to more complete offerings (e.g. integrated solution) (Oliva and Kallenberg, 2003; Penttinen and Palmer, 2006). Based on the continuum of the relationship development and the continuum of service offering development, Penttinen and Palmer (2006) have constructed a framework that can be seen in figure 1. The horizontal axis describes the nature of the relationship based on the continuum from transactional to relational approach and the vertical axis describes the continuum of the service offering and its completeness. 


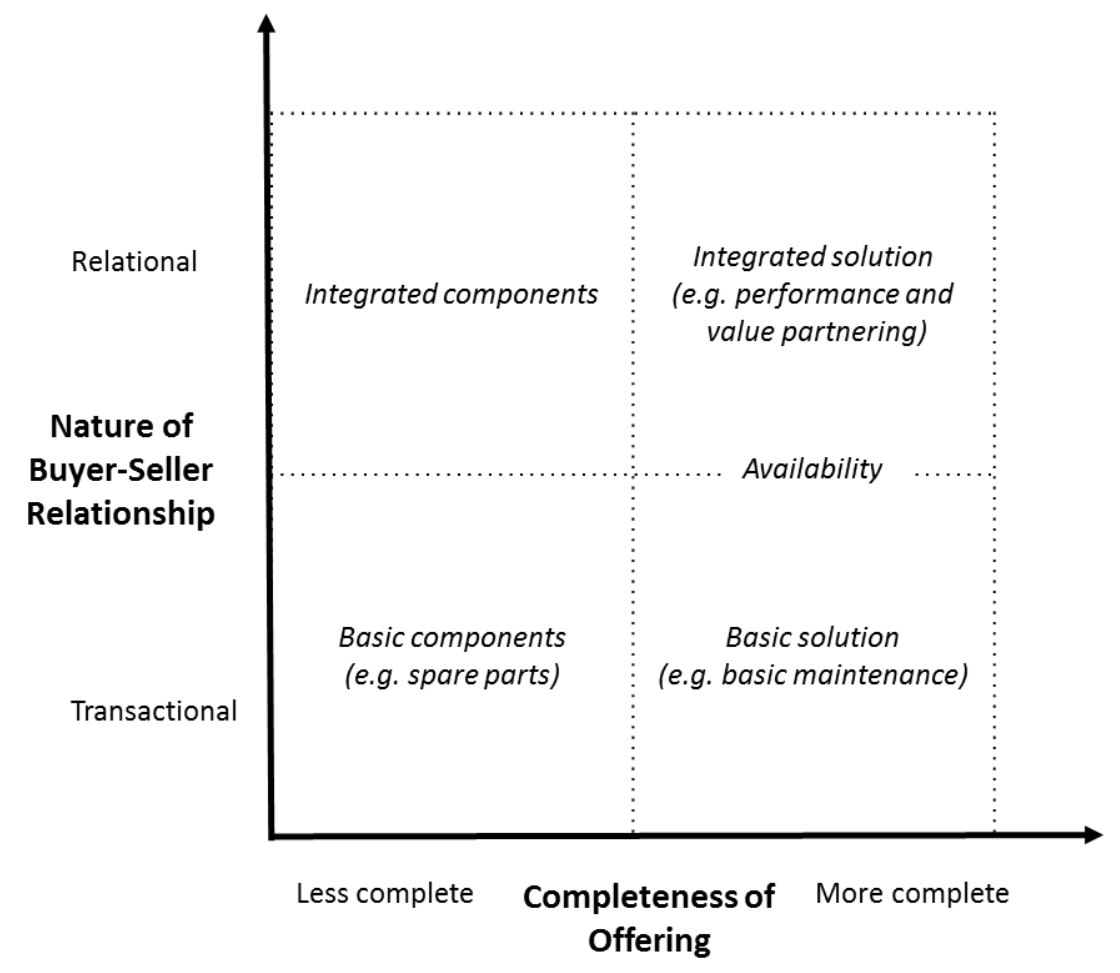

Figure 1. Development of the relationship and service offering (adapted from Penttinen and Palmer, 2006).

The less complete offerings are often simple but also limited in the differentiation for the customer. On the other hand the more complete offerings are extensions in meeting customer needs but they are also more complex on the relationship side and can require for example more extensive information exchange (Penttinen and Palmer, 2006). In maintenance services the service offering also often ranges from less complete offerings like spare parts to a complete operation and maintenance contract where focus is on the business process and mutual value creation on the long-term (Rekola and Haapio, 2009). In basic services the focus is on price and no long-term contracts or relationship development (e.g. spare parts, basic maintenance). The extended basic is similar to the basic services but based on a long term contract (e.g. technical support). Rekola and Haapio (2009) mention as the most popular maintenance service form availability (full services/ outsourcing) where the focus is on preventive maintenance and the relationship is based on a service contract (incl. services like maintenance, spare parts, training and inspections). Availability services place in the middle of basic maintenance and performance partnering in figure 1. Maintenance services that would fall more on the relational side are performance partnering where the focus is on OEE (overall equipment effectiveness) and value partnering where focus is on the customer's business processes instead of only maintenance. Both service offerings are based on long-term contracts and mutual service development, and will require intimate service relationships. In knowledge-intensive business service offerings the co-creation of value is also characterized by the positive moderating role of relationship learning (Kohtamäki and Partanen, 2016). Even though value partnering sounds profitable not all have to aim for it. It can involve complicated contractual issues and other costs associated to the close relationship and in addition it requires a great deal of mutual trust. Axelsson and Wynstra (2002) also discuss that sometimes losing the competitive side of the relationship can result in increasing the cost. (Rekola and Haapio, 2009) 
Every box in the relationship and offering quadrat of Penttinen and Palmer (2006) can be profitable as long as the offering suits the needs of all parties and the relationship status is on the required level. However, the more the focus is on the service side of the offering the more the parties should focus on realized value (value-in-use) instead of focusing only on the potential value at the point of sales (value-in-exchange) (Grönroos and Helle, 2010). Perceptions of the value created typically vary between individuals from different functions and from different companies and therefore it is important to discuss and actively give feedback so that the value propositions can be revised, organizational learning can be enhanced, and resources assigned in the most profitable way (Lambert and Enz, 2012). The success of a maintenance service network is dependent on the partners' ability to collaborate (Bengtsson and Kock, 2000). Overall, the core of successful relationships between different service partners is a common view of the objectives, trust and commitment (Anderson and Narus, 1998; Rosqvist et al., 2009).

\section{Methodology}

\section{Design and procedure}

The study is based on a questionnaire that consisted of background questions, the main part capturing the service value of maintenance, and a final part where measurement and performance related questions were asked as additional information. The main part comprises 32 value propositions measuring maintenance services as a multidimensional phenomenon with both financial and non-financial service elements. The value elements behind the propositions were selected originally based on a literature review. To maximize the validity of the construct the elements were reviewed and revised with a group of researchers and maintenance experts. First a pre-assignment was conducted where the experts determined the value of different maintenance services without the preliminary list based on the literature review so that guided responses could be avoided. Secondly the group was asked to critically revise the created lists based on the literature review and pre-assignment. Based on the revision two elements were added: safety at work and environmental safety as the impact of maintenance on safety issues is brought up repeatedly and it is also one of the main focus points in specific maintenance literature and forums (e.g. EU-OSH, 2012; EFNMS, 2016; Lind et al., 2008; The Finnish Maintenance Society, 2007). In addition some improvements in wording relating the other elements were made. Each element was then turned into two value propositions to communicate the value creating characteristics behind the element clearly to the respondents (Ballantyne et al. 2011). The elements of maintenance service value and their propositions are presented in table 2 . For each of the 32 value propositions, the respondents were asked to indicate their opinion on a five-point Likert scale with end points of 'strongly disagree' (1) to 'strongly agree' (5). The unit of analysis is an individual respondent's perception on maintenance service value on organizational level as the respondents were not required to provide absolute values. The questionnaire was pretested among maintenance experts and some minor improvements were made before publicly sending out the questionnaire.

\section{Participants and data collection}

The data for the study was collected with an online-questionnaire from Finnish companies that are either customers or service providers (pure service providers or also equipment providers) of maintenance in an industrial context. Overall, the questionnaire link was sent to 345 maintenance service professionals. The primary source for the contacts was a nationwide actor Finnish Maintenance Society Promaint, which has a diverse network of companies acting in the maintenance field. Finland is a good testing ground as outsourcing of maintenance is quite 
common and the maintenance sector in overall a significant industry due to the aging industrial assets (Hatinen et al., 2012; The Finnish Maintenance Society, 2007). The survey was conducted between January-March 2013. The contact persons received two reminders after the first message every two weeks. The process resulted in a total of 83 completed questionnaires, representing a final response rate of $24 \%$.

To avoid the common method bias of social desirability (Podsakoff et al., 2003) the respondents were encouraged to answer from their own viewpoint as truthfully as possible. The respondents were allowed to answer anonymously. By allowing anonymous responses the respondents are less likely to edit their responses according to social desirability. In addition, the survey questions were constructed carefully by paying attention to the wording and clarity. The questions were also pretested and revised by a group of researchers and maintenance experts and this should also reduce the possibility of common method bias. To check the nonresponse bias, the differences between different respondent groups were tested. The respondents were divided into three groups based on their response time: the first respondents, the respondents after the first reminder and the respondents after the second and last reminder. The results of the Kruskall-Wallis $\mathrm{H}$ test (as the data is not normally distributed) showed that there are no significant differences (at the 0.05 significance level) between the three groups. Based on the test it can be assumed that the received responses present well the whole sample.

Table 2. Value propositions and the original references

\begin{tabular}{|c|c|c|}
\hline \multirow{2}{*}{$\begin{array}{l}\text { Value element } \\
\text { Availability } \\
\text { (Ma et al. 2005) }\end{array}$} & \multicolumn{2}{|c|}{ Proposition } \\
\hline & $\mathrm{P} 1$ & $\begin{array}{l}\text { "The maintenance tasks are appropriate and maintainability and repair are } \\
\text { easy." } \\
\text { "The operators carry out their part of the in use maintenance operations and } \\
\text { enhance the maintainability of the item." }\end{array}$ \\
\hline Safety at work & $\begin{array}{l}\text { P3 } \\
\text { P4 }\end{array}$ & $\begin{array}{l}\text { "The operational conditions and safety increase along the service." } \\
\text { "Maintenance is performed according to safety policies" }\end{array}$ \\
\hline Environmental safety & P5 & $\begin{array}{l}\text { "The maintenance service performer recognizes the environmental safety } \\
\text { hazards." } \\
\text { "Maintenance is performed according to environmental safety policies." }\end{array}$ \\
\hline $\begin{array}{l}\text { Technical quality } \\
\text { (Matthyssens, and } \\
\text { Vandenbempt, 1998; } \\
\text { Ojanen et al. 2012B) }\end{array}$ & $\begin{array}{l}\text { P7 } \\
\text { P8 }\end{array}$ & $\begin{array}{l}\text { "The maintenance service outcome is as expected." } \\
\text { "The maintenance service outcome is sustained for the promised time." }\end{array}$ \\
\hline $\begin{array}{l}\text { Flexibility } \\
\text { (Ojanen et al. 2012B; } \\
\text { Barry and Terry 2008; } \\
\text { Kremic et al., 2006; } \\
\text { Malleret 2006) }\end{array}$ & $\begin{array}{l}\text { P9 } \\
\text { P10 }\end{array}$ & $\begin{array}{l}\text { "The maintenance service partner can suit the needs of the company (e.g. } \\
\text { delivery time)" } \\
\text { "The maintenance services are tailored based on need." }\end{array}$ \\
\hline $\begin{array}{l}\text { Reliability } \\
\text { (Ojanen et al. 2012B; } \\
\text { Barry and Terry 2008) }\end{array}$ & $\begin{array}{l}\text { P11 } \\
\text { P12 }\end{array}$ & $\begin{array}{l}\text { "The maintenance service cooperation is executed on time and as promised." } \\
\text { "The maintenance service cooperation is based on confidentiality." }\end{array}$ \\
\hline $\begin{array}{l}\text { Operator knowledge } \\
\text { (Songailiene et al. 2011; } \\
\text { Brito et al. 2007) }\end{array}$ & $\begin{array}{l}\mathrm{P} 13 \\
\mathrm{P} 14\end{array}$ & $\begin{array}{l}\text { "The maintenance service provider has the knowledge to solve upcoming } \\
\text { problems." } \\
\text { "The maintenance service operators are professionally skilled and qualified." }\end{array}$ \\
\hline $\begin{array}{l}\text { Orderliness } \\
\text { (Matthyssens and } \\
\text { Vandenbempt, 1998; } \\
\text { Barry and Terry 2008) }\end{array}$ & $\begin{array}{l}\text { P15 } \\
\text { P16 }\end{array}$ & $\begin{array}{l}\text { "The resources and timetable of the maintenance service can be planned well } \\
\text { in advance." } \\
\text { "The maintenance service operations are developed in cooperation." }\end{array}$ \\
\hline $\begin{array}{l}\text { Reputation } \\
\text { (Ramsey and Wagner } \\
\text { 2009) }\end{array}$ & $\begin{array}{l}\text { P17 } \\
\text { P18 }\end{array}$ & $\begin{array}{l}\text { "The current reputation of the maintenance service partner is good." } \\
\text { "The previous experiences with the maintenance service partner have been } \\
\text { positive." }\end{array}$ \\
\hline
\end{tabular}


Ali-Marttila, M., Marttonen-Arola, S., Kärri, T., Pekkarinen, O., \& Saunila, M. (2017). Understand what your maintenance service partners value. Journal of quality in maintenance engineering, 23(2), 144-164.

\begin{tabular}{|c|c|c|}
\hline $\begin{array}{l}\text { Relationship } \\
\text { (Ramsey and Wagner } \\
\text { 2009; Barry and Terry } \\
\text { 2008; Ojanen et al. } \\
\text { 2012B) }\end{array}$ & $\mathrm{P} 20$ & $\begin{array}{l}\text { "The maintenance service cooperation works well considering the conditions } \\
\text { of all partners." } \\
\text { "The information exchange works between the maintenance service partners." }\end{array}$ \\
\hline $\begin{array}{l}\text { Contracts } \\
\text { (McDonough et al., } \\
\text { 2006; Ramsey and } \\
\text { Wagner 2009; } \\
\text { Songailiene et al. 2011) }\end{array}$ & $\mathrm{P} 22$ & $\begin{array}{l}\text { "The maintenance service warranty and terms of payment are kept and } \\
\text { executed as promised." } \\
\text { "The risks and responsibilities considering the maintenance services are } \\
\text { shared between the customer and the service provider." }\end{array}$ \\
\hline $\begin{array}{l}\text { Total solutions } \\
\text { (Matthyssens and } \\
\text { Vandenbempt, 1998; } \\
\text { Stremersch et al. 2001) }\end{array}$ & $\begin{array}{l}\mathrm{P} 23 \\
\mathrm{P} 24\end{array}$ & $\begin{array}{l}\text { "The maintenance service cooperation covers comprehensively the whole } \\
\text { maintenance services (from management to execution)." } \\
\text { "The maintenance service covers the whole life span of the item." }\end{array}$ \\
\hline $\begin{array}{l}R \& D \\
\text { (McDonough et al., } \\
\text { 2006; Ojanen et al., } \\
\text { 2012B; Walter et al. } \\
\text { 2001) }\end{array}$ & P26 & $\begin{array}{l}\text { "Own research and development can be developed with the maintenance } \\
\text { service partner." } \\
\text { "The maintenance service partner can provide information and knowledge } \\
\text { related to the development of R\&D activities." }\end{array}$ \\
\hline $\begin{array}{l}\text { Price } \\
\text { (Songailiene et al. 2011; } \\
\text { Brito et al. 2007) }\end{array}$ & $\begin{array}{l}\mathrm{P} 27 \\
\mathrm{P} 28\end{array}$ & $\begin{array}{l}\text { "The price paid for the maintenance service corresponds with the received } \\
\text { service." } \\
\text { "The price is negotiated in cooperation with the maintenance service partner." }\end{array}$ \\
\hline $\begin{array}{l}\text { Access to markets } \\
\text { (Kremic et al., 2006; } \\
\text { Ramsey and Wagner } \\
\text { 2009; Walter et al. 2001) }\end{array}$ & $\begin{array}{l}\text { P29 } \\
\text { P30 }\end{array}$ & $\begin{array}{l}\text { "The maintenance service cooperation enables contact with new customers." } \\
\text { "The maintenance service cooperation enables starting a new type of } \\
\text { business." }\end{array}$ \\
\hline $\begin{array}{l}\text { Asset management } \\
\text { (Ojanen et al. 2012B) }\end{array}$ & $\begin{array}{l}\mathrm{P} 31 \\
\mathrm{P} 32\end{array}$ & $\begin{array}{l}\text { "The maintenance service partner is responsible for the spare part storage so } \\
\text { that it does not tie your own resources and capital." } \\
\text { "The maintenance service partner owns the fixed assets, for example, the } \\
\text { maintained items so that they do not stress your own balance sheet." }\end{array}$ \\
\hline
\end{tabular}

\section{Description of the data}

As the background information of the respondents in table 3 show, 39\% of the respondents represented large companies (over 250) workers, and thus the majority represented middle sized or small companies. The majority $(57 \%)$ of the responses were received from middle management, for example from maintenance managers, $20 \%$ of the respondents represented senior management, and the rest $(23 \%)$ represented mainly consultants and supervisors. One third $(39 \%)$ of the respondents represented companies on the maintenance service customer side and the rest $(61 \%)$ represented the service provider side.

Table 3. Descriptive statistics of the sample $(\mathrm{N}=83)$

\begin{tabular}{lr|r}
\hline & Number & Percentage \\
\hline Number of employees & & \\
under 10 & 7 & $8 \%$ \\
$10-49$ & 19 & $23 \%$ \\
$50-249$ & 25 & $30 \%$ \\
over 250 & 32 & $39 \%$ \\
& & \\
Approximate turnover $(\epsilon)$ & & \\
under 1 million & 9 & $11 \%$ \\
1-20 million & 23 & $28 \%$
\end{tabular}


Ali-Marttila, M., Marttonen-Arola, S., Kärri, T., Pekkarinen, O., \& Saunila, M. (2017). Understand what your maintenance service partners value. Journal of quality in maintenance engineering, 23(2), 144-164.

\begin{tabular}{ll|l}
$21-100$ million & 21 & $25 \%$ \\
over 100 million & 30 & $36 \%$ \\
& & \\
Position of the respondent & 17 & $20 \%$ \\
senior management & 47 & $57 \%$ \\
middle management & 19 & $23 \%$ \\
other & & \\
& & \\
Organization unit primarily & 32 & $39 \%$ \\
maintenance service customer & 36 & $43 \%$ \\
maintenance service provider & 15 & $18 \%$ \\
equipment and maintenance service provider &
\end{tabular}

Proposition P4 "maintenance is performed according to safety policies" had the highest mean (4.74) on a scale from 1-5 (see table 4). It seems that safety awareness is still highlighted in organizations. Also P7 "the maintenance service outcome is as expected" (4.55), P11 "The maintenance service cooperation is executed on time and as promised" (4.54), P12 "The maintenance service cooperation is based on confidentiality." (4.66) and P14 "The maintenance service operators are professionally skilled and qualified"(4.56) were valued very high (above 4.5). This emphasize the role of well-functioning relationships. It is important that the partners are reliable and doing what they promise.

Interestingly the propositions related to relationships and collaboration were mainly valued below average (4.15) as P9 "The maintenance service partner can suit the needs of the company (e.g. delivery time)" (3.72), P22 "The risks and responsibilities considering the maintenance services are shared between the customer and the service provider" (3.85), P24 "The maintenance service covers the whole life span of the item" (3.83), P25 "Own research and development can be developed with the maintenance service partner" (3.69), P26 "The maintenance service partner can provide information and knowledge related to the development of R\&D activities" (3.63), P29 "The maintenance service cooperation enables contact with new customers" (3.78), P30 "The maintenance service cooperation enables starting a new type of business" (3.43) and P31 "The maintenance service partner is responsible for the spare part storage so that it does not tie your own resources and capital" (3.42) were valued below (4.00). It could be concluded that well-functioning relationships are valued but the elements behind are mainly not identified to actually get the positive synergies of relationships.

Based on the survey results first an explorative factor analysis was conducted to capture comprehensively the scale to measure value of maintenance services. After this a cluster analysis was conducted to identify respondent groups characterized by their attitude towards different value creation strategies and readiness to collaborate.

\section{Findings}

\section{Factor analysis}

To complete the multidimensional measurement scale generalized least squares analysis was conducted to group the propositions into more comprehensive groups and find possible hidden elements. An exploratory analysis with Oblimin with Kaiser Normalization rotation produced 
seven factors with an eigenvalue over 1.00. The model explains $60 \%$ of the variance (see table 4). The value of the Keiser-Meyer-Olkin (KMO) measure of sampling adequacy was 0.784 , which can be considered good.

Table 4. Factor analysis results

\begin{tabular}{|c|c|c|c|c|c|c|c|c|c|c|}
\hline Variable & Mean & S.D. & $\begin{array}{l}\text { Factor } \\
1 \\
\end{array}$ & $\begin{array}{l}\text { Factor } \\
2 \\
\end{array}$ & $\begin{array}{l}\text { Factor } \\
3 \\
\end{array}$ & $\begin{array}{l}\text { Factor } \\
4 \\
\end{array}$ & $\begin{array}{l}\text { Factor } \\
5 \\
\end{array}$ & $\begin{array}{l}\text { Factor } \\
6 \\
\end{array}$ & $\begin{array}{l}\text { Factor } \\
7 \\
\end{array}$ & Comm. \\
\hline P18 & 4.198 & 0.66 & 0.354 & & & & & & & 0.672 \\
\hline $\mathrm{P} 22$ & 3.850 & 0.90 & 0.370 & & & & & & & 0.757 \\
\hline P26 & 3.627 & 1.02 & 0.487 & & & & & & & 0.892 \\
\hline P29 & 3.780 & 1.14 & 0.994 & & & & & & & 0.867 \\
\hline P30 & 3.427 & 1.09 & 0.851 & & & & & & & 0.851 \\
\hline P14 & 4.563 & 0.63 & & 0.553 & & & & & & 0.850 \\
\hline P17 & 4.280 & 0.65 & & 0.501 & & & & & & 0.764 \\
\hline P20 & 4.272 & 0.84 & & 0.711 & & & & & & 0.923 \\
\hline $\mathrm{P} 21$ & 4.268 & 0.88 & & 0.625 & & & & & & 0.838 \\
\hline P27 & 4.329 & 0.82 & & 0.395 & & & & & & 0.862 \\
\hline P28 & 4.363 & 0.68 & & 0.448 & & & & & & 0.563 \\
\hline P31 & 3.415 & 1.12 & & 0.438 & & & & & & 0.668 \\
\hline P3 & 4.337 & 0.72 & & & 0.583 & & & & & 0.719 \\
\hline $\mathrm{P} 12$ & 4.659 & 0.55 & & & 0.444 & & & & & 0.730 \\
\hline $\mathrm{P} 25$ & 3.687 & 1.05 & & & 0.464 & & & & & 0.888 \\
\hline $\mathrm{P} 1$ & 4.205 & 0.95 & & & & 0.725 & & & & 0.836 \\
\hline $\mathrm{P} 2$ & 4.185 & 1.05 & & & & 0.430 & & & & 0.773 \\
\hline P15 & 4.012 & 0.94 & & & & 0.511 & & & & 0.738 \\
\hline P13 & 4.470 & 0.65 & & & & & 0.481 & & & 0.857 \\
\hline $\mathrm{P} 23$ & 4.060 & 0.93 & & & & & 0.395 & & & 0.746 \\
\hline P24 & 3.829 & 1.03 & & & & & 0.744 & & & 0.735 \\
\hline P4 & 4.738 & 0.47 & & & & & & 0.847 & & 0.771 \\
\hline P6 & 4.481 & 0.70 & & & & & & 0.676 & & 0.764 \\
\hline P7 & 4.554 & 0.65 & & & & & & 0.578 & & 0.889 \\
\hline P8 & 4.238 & 0.82 & & & & & & 0.503 & & 0.777 \\
\hline P11 & 4.542 & 0.57 & & & & & & 0.353 & & 0.739 \\
\hline P19 & 4.146 & 0.79 & & & & & & 0.408 & & 0.842 \\
\hline P9 & 3.723 & 0.87 & & & & & & & 0.739 & 0.643 \\
\hline P10 & 4.241 & 0.73 & & & & & & & 0.525 & 0.683 \\
\hline $\begin{array}{l}\text { Cronbach's } \\
\text { alpha }\end{array}$ & & & 0.812 & 0.830 & 0.574 & 0.593 & 0.659 & 0.874 & 0.498 & \\
\hline Eigenvalue & & & 6.840 & 5.593 & 1.476 & 1.926 & 1.241 & 1.083 & 1.076 & \\
\hline $\begin{array}{l}\text { Percentage } \\
\text { of variance } \\
\text { explained }\end{array}$ & & & 21.375 & 17.477 & 4.612 & 6.017 & 3.877 & 3.384 & 3.362 & \\
\hline Cumulative & & & 21.375 & 38.857 & 43.464 & 49.481 & 53.358 & 56.742 & 60.104 & \\
\hline
\end{tabular}

Notes: *Generalized Least Squares. Oblimin with Kaiser Normalization rotation. Loadings above 0.35 are shown (Castello and Osborne, 2005). KMO measure of sampling adequacy 0.784.

**Variables P5, P16 were removed from the final results as they loaded on separate factors as the only ones. In addition variable P32 was removed as it loaded negatively on the fourth factor. 
Factor 1. The first factor explains 21.4 percent of the total variance of the data. It received five loadings ranging from 0.354 to 0.994 . "The maintenance service cooperation enables contact with new customers" had the strongest loading (0.994). The other propositions "The maintenance service cooperation enables starting a new type of business" (0.851), "The maintenance service partner can provide information and knowledge related to the development of R\&D activities" (0.487), "The risks and responsibilities considering the maintenance services are shared between the customer and the service provider" $(0.370)$ and "The previous experiences with the maintenance service partner have been positive" $(0.354)$ describe the positive synergies of relationships and therefore the first factor represents "relationship synergies".

Factor 2. The second factor explains 17.5 percent of the total variance of the data. Altogether seven propositions loaded on this factor ranging from 0.395 to 0.711 . "The information exchange works between the maintenance service partners" had the strongest loading (0.711). The others were "The maintenance service warranty and terms of payment are kept and executed as promised" (0.625), "The maintenance service operators are professionally skilled and qualified" (0.553), "The current reputation of the maintenance service partner is good" $(0.501)$, "The price is negotiated in cooperation with the maintenance service partner" $(0.448)$, "The maintenance service partner is responsible for the spare part storage so that it does not tie your own resources and capital" $(0.438)$ and "The price paid for the maintenance service corresponds with the received service" $(0.395)$. These features represent how well the contract is executed and if the service partner can be considered as reliable. Altogether they represent the second factor "reliability of the service partner".

Factor 3. The third factor explains 4.6 percent of the total variance. Three items loaded on the factor ranging from 0.444 to 0.583 . The strongest loading was on the item "The operational conditions and safety increase along the service" $(0.583)$. The others were "Own research and development can be developed with the maintenance service partner" (0.464) and "The maintenance service cooperation is based on confidentiality" $(0.444)$. The propositions describe development activities and especially if done together mutual trust is required. Therefore the third factor represents "development".

Factor 4. The fourth factor explains 6.0 percent of the total variance of the data and three items loaded on it. The loadings ranged from 0.725 to 0.430 . "The maintenance tasks are appropriate and maintainability and repair are easy" $(0.725)$ had the strongest loading. Also "The resources and timetable of the maintenance service can be planned well in advance" $(0.511)$ and "The operators carry out their part of the in use maintenance operations and enhance the maintainability of the item" (0.430) describe the easiness of operations and maintainability. Altogether these features represent "availability".

Factor 5. The fifth factor explains 3.9 percent of the total variance. Three value propositions loaded on the factor ranging from 0.395 to 0.744 . "The maintenance service covers the whole life span of the item" $(0.744)$ had the strongest loading. The others were "The maintenance service provider has the knowledge to solve upcoming problems" (0.481) and "The maintenance service cooperation covers comprehensively the whole maintenance services (from management to execution)" (0.395). The propositions describe comprehensive solutions where the ability to solve and take care of problems is on the partners side. Altogether the fifth factor can be considered as the "service solutions and problem solving ability".

Factor 6. The sixth factor explains 3.4 percent of the total variance of the data and overall six propositions loaded on it. Loadings ranged from 0.353 to 0.847 . The strongest loading was on 
the proposition "maintenance is performed according to safety policies" (0.847). Also " maintenance is performed according to environmental safety policies" (0.679), "The maintenance service outcome is as expected" $(0.578)$, "The maintenance service outcome is sustained for the promised time" (0.503), "The maintenance service cooperation works well considering the conditions of all partners" $(0.406)$ and "The maintenance service cooperation is executed on time and as promised" $(0.353)$ are part of the sixth factor. As the items represent safety, environmental and quality aspects and also consider the reliability the sixth factor represents altogether the elements of "EHSQ (environment, health, safety and quality)".

Factor 7. The seventh factor explains 3.4 percent of the total variance of the data. It received two loadings ranging from 0.525 to 0.739 . The strongest loading was on "The maintenance service partner can suit the needs of the company (e.g. delivery time)" (0.739) and also the second item "The maintenance services are tailored based on need" $(0.525)$ represented flexibility of the services and therefore "adaptability to suit different situations" represents the seventh factor.

Construct validity of the measurement scale was assured by developing pre-understanding of the value elements with a literature review and building new elements based on theories and expert opinion. The finalizing of the questionnaire was also done with a group of researchers and maintenance experts to ensure content validity so that the solution captures the main domain of the maintenance service value construct. Criterion validity was assessed based on correlation coefficients between different value propositions. All the propositions had significant correlations relating to other propositions which is a good starting point for factor analysis as partial correlations were small based on the measure of sampling adequacy.

Reliability of the results was tested by measuring the internal consistency of the created factors with Cronbach's alpha. As can be seen in table 4 the Cronbach's alpha is greater than 0.50 in factors 1-6. The reliability of the analysis can be concluded to be sufficient when considering these factors especially as they also included new scales. In the seventh factor the alpha value is 0.49 which is below the recommended. This indicates that reliability of the factor can be questioned and the results considering this factor should be used with caution. The overall alpha value of the scale with the remaining 29 variables is 0.915 , which means that the reliability of the total construct is supported. The created factors form the base for the multidimensional scale measuring maintenance service value.

\section{Cluster analysis}

The computed factor scores were further used for cluster analysis. The amount of clusters was based on the hierarchical cluster analysis and the final clustering was done with K-mean clustering. The cluster analysis revealed that based on what elements the actors emphasize they can be divided into three main strategy types (table 5):

1. Collaboration oriented partners

2. Basic partners

3. Quality oriented partners

The first cluster consists of 28 respondents. All the created factors got positive values (higher than the average) and especially Factor 1 "relationship synergies"(0.65), Factor 3 "development" (0.53), Factor 4 "availability" (0.56) and Factor 5 "service solutions and problem solving ability" $(0.43)$ got high values compared to the other clusters. The respondents seem to highlight the positive effects of relationships and outsourcing, what can be achieved more by doing things together. They identify that there are multiple elements that affect the 
maintenance service value in addition to the short-term transaction of the service. Therefore the cluster was named the collaboration oriented partners.

Table 5. Cluster analysis results

\begin{tabular}{llccc}
\hline & & \multicolumn{3}{c}{ Clusters } \\
& Mean & $1(\mathrm{~N}=28)$ & $2(\mathrm{~N}=20)$ & $3(\mathrm{~N}=34)$ \\
\cline { 2 - 5 } Factor 1 Relationship synergies & 3,7293 & 0,65 & $-0,28$ & $-0,37$ \\
Factor 2 Reliability of the service partner & 4,1481 & 0,40 & $-0,61$ & 0,02 \\
Factor 3 Development & 4,2114 & 0,53 & $-0,63$ & $-0,06$ \\
Factor 4 Availability & 3,7348 & 0,56 & $-0,80$ & 0,01 \\
Factor 5 Service solutions and problem solving ability & 4,1341 & 0,43 & $-0,55$ & $-0,03$ \\
Factor 6 EHSQ & 4,3699 & 0,34 & $-0,68$ & 0,12 \\
Factor 7 Adaptability to suit different situations & 3,9939 & 0,06 & $-0,34$ & 0,15 \\
\hline
\end{tabular}

The second cluster consisted of 20 respondents. Compared to the other two clusters this one got negative values in all of the factors. The respondents in this group did not see special value in any of the value propositions and especially the Factor 4 "availability" got low values compared to the other clusters. Easiness of operations is not considered important and overall maintenance services are considered as a transaction amongst other functions and no special value is seen in the relationship. Therefore this cluster was named basic partners. The service is ordered and the service provider provides it as ordered and not much other expectations than the transaction is thought of.

The third cluster was the biggest one and it consisted of 34 respondents. Factor 7 "adaptability to suit different situations" and Factor 6 "EHSQ" got positive values and in addition factor 4 "availability" and Factor 2 "reliability of the service partner" got slightly higher values than the average. Interestingly factor 1 "relationship synergies" received negative values so that it is expected less than on average. Therefore the respondents in this cluster can be characterized as interested in the outcome being as discussed and the partner trustworthy working according to policies but there is not necessarily interest to take the relationship one step further to think of co-creation of maintenance services or relationship synergies. There are expectations what goes towards the service but not necessarily towards the relationship behind it. This cluster was named the quality oriented partners.

In addition the descriptive statistics were analyzed together with the cluster membership (appendix 1). Medium sized service providers were the biggest group in the first cluster "collaboration oriented partners". Most of the customers were in the third cluster "quality oriented partners" and in the second cluster "basic partners" the membership respondents were from bigger companies both on the customer and service provider side. Interestingly the first cluster outperformed slightly the other two clusters in operative and financial performance based on the respondents own estimate. The respondents may be overly positive or are the positive synergies making an advantage? It should be noted though that the group was rather small to make certain assumptions.

The analysis identified clear differences between the clusters and this was also supported statistically. When comparing the clusters also statistically significant differences were found between the factors. They are very significant (0.000) in the first six factors and significant $(0.02)$ in the seventh factor "adaptability to suit different situations". 
Ali-Marttila, M., Marttonen-Arola, S., Kärri, T., Pekkarinen, O., \& Saunila, M. (2017). Understand what your maintenance service partners value. Journal of quality in maintenance engineering, 23(2), 144-164.

\section{Discussion}

\section{Value creation}

This research contributes to the value creation and industrial service development literature by providing insight into the value creating elements of maintenance services. In previous studies the comprehensive nature of maintenance service value has received less attention and the literature has focused more on the technical and financial aspects. The nature of business has changed as service suppliers and equipment providers are now bringing the service aspect into maintenance and this underlines the need to evaluate the value of maintenance services. To capture the comprehensive nature of maintenance service value both financial and nonfinancial elements need to be considered (e.g. Liyanage and Kumar, 2003; Ojanen et al., 2012A; Toossi et al., 2013). To improve the current understanding of the value creating elements in maintenance services, this study explored comprehensively the value creating propositions behind maintenance and identified relationship synergies, reliability of the service partner, development, availability, service solutions and problem solving ability, EHSQ and adaptability to suit different situations as factors that capture the value creating aspects of the services. The building and testing of the multidimensional maintenance service value scale provides a new conceptualization of the value creating elements and extends systematic ways to understand and measure the service value. Integrated measures are needed by the customers and service providers as this helps the building of sustainable relationships and networks (Ahonen et al., 2010; Panesar and Markeset, 2008; Reinartz and Ulaga, 2008).

In addition, this research examined how the different factors of the service value scale are affected when considering different actors in industrial maintenance. Based on the findings the actors were divided into three strategy types. The actors of the first strategy type "collaboration oriented partners" agreed that all the factors of the maintenance service value scale are important. This means that instead of a single value proposition the combination of different elements is considered meaningful. In the second strategy type "the basic partners" the actors valued less the certain service aspects than the first cluster but still the combination of different elements was considered at least somewhat important. The third strategy type "quality oriented partners" emphasized especially the quality factors and adaptability. The financial and operative performances were considered as good within the collaboration oriented partners (Appendix 1). This could indicate that if the business is running smoothly there is also time to think of development ideas and common projects with the service partners to gain positive synergies. On the other hand, if these are not functioning well there is no time and/or desire to consider the other elements around value than the financial one. All the energy goes into running the operative business and results in basic partners. The big actors were a major group in the basic cluster as the medium and small sized actors were in the two others. For the big companies the maintenance service can be just another function besides the main functions of the company but the smaller organizations have to aim for value partners. The big companies can dictate the relationship and keep it transaction based. Also Hallikas et al. (2014) have received similar results regarding the division of respondents when considering industrial services. It seems to be common that the respondents divide into groups based on the importance of the relationship level maintained and its positive effects.

Although the research and practice has moved from cost to value-centric the findings show that the actors in the maintenance field still have very varying strategies towards value creation: some actors are very transaction oriented versus others who are very relational oriented. Especially a lot of customers seem to consider maintenance as a cost and prefer transaction based service relationships as a value creating strategy like Murthy et al. (2015) suggests. Considering the value creation potential of maintenance the cost-centric view might be harmful 
as it guides the decisions short-term. Maintenance and other knowledge-intensive business services should be managed with a long-term business oriented view to be able to enable the learning process in a relationship and see the value achieved in the long run (Kohtamäki and Partanen, 2016; Liyanage and Kumar, 2003; Parida and Kumar, 2006). To proceed from transactional relationships towards more collaborative relationships mutual understanding of the comprehensive maintenance service value needs to be attained. This emphasizes the role of communication between the service actors.

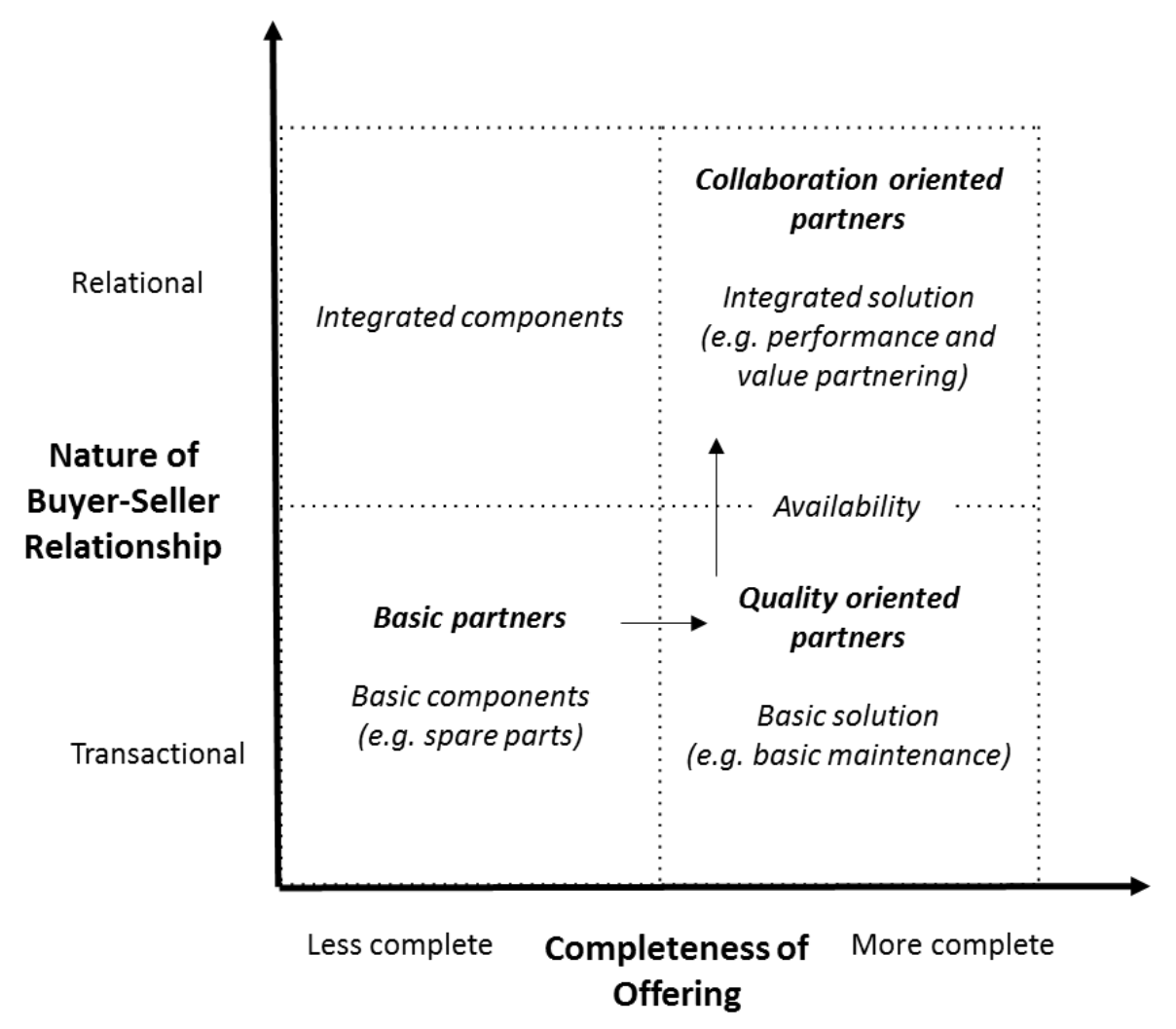

Figure 2. Framework for possible value creation strategies at different relationship and offering levels (adapted from Penttinen and Palmer, 2006).

Communication and mutual understanding of the value creating elements is also important when considering the development of the relationship and service offering. For the transactional oriented actors the less complete service offerings like spare parts and basic solutions are suitable (Penttinen and Palmer, 2006; Rekola and Haapio, 2009). However, the more complete the offerings are (like availability and performance partnering) the more the relationship focus should shift on the relational side and take comprehensively the value creating aspects of maintenance services into consideration. The development path is illustrated in figure 2. The heterogeneity among customers and service providers is probably one reason why the building of successful service networks is considered complex. Often the offerings and relationship nature do not match and this causes conflicts and dissatisfaction among service partners. To achieve the best value in the relationships the value creating elements need to be actively communicated between actors so that the relationship levels and offerings will match. Basic, quality and collaboration oriented partners will find their counterparts. 


\section{Managerial implications}

Outsourcing is done for multiple reasons (e.g. some aim for cost savings and some for special know-how) and therefore open communication is important in defining the goals of the service relationship. Service providers need to consider what the customer needs are and also what the readiness of the customer is to collaborate if aiming for more complete offerings and also other than cost saving benefits (e.g. flexibility, special know-how, R\&D). In addition, the service providers need to ensure that they address all the value creating elements when providing complete offerings like performance partnering. The measurement scale can be used to benchmark the current level of practices and aimed service level. Also the customers need to ensure that they consider comprehensively the value creating elements when procuring maintenance services and ensure that their partner is capable of providing the needed service level (Toossi et al., 2013). It is important that right maintenance services are created with the right partners so that the best value can be achieved in the relationship. The framework (figure 2) presented above helps the service provides see what relationship style their offering requires and the customers to identify how complete they want their maintenance services and relationships to be and what this requires. For example if they are currently operating with basic services and desire to move towards availability or performance partnering a strategy shift towards more relational relationships is required to be able to move on the continuum.

Maintenance service value is complex to manage but by using the created factors some systematics can be brought into the process. The scale can be used as a base for network and company level value measurement building to communicate and create mutual understanding of the value creating elements between service partners. The core for successful service relationships between different service partners as Rosqvist et al. (2009) highlight is a common view of the maintenance objectives that drive from strategic objectives and KPI's. The multidimensional scale of the value creating factors could be used as a base to determine suitable performance measures and objectives for the maintenance service. Assessment of the value and assessment of the cost of the service could be based on this. A comprehensive measurement scale helps the companies to extend their understanding beyond the cost-centric view towards the value-added processes what is emphasized e.g. by Liyanage and Kumar (2003) as well as Parida and Kumar (2006). Identifying value elements helps the parties understand different cost and benefit elements they have previously possibly been unaware of (Anderson and Narus, 1998). The service network can be moved step by step from traditional arm's length towards collaborative value creation.

\section{Limitations and future research}

There are some limitations to the study that should be taken into account. The data used in the study was based on subjective responses of company managers and other employees. It is possible that the subjectivity has biased the results of the study. However, the aim of this study was not to find the absolute value but more importantly support the comprehensive value discussion and therefore the possibility of somewhat biased responses should not be a major issue. It is also a limitation that the survey was conducted anonymous which disabled the possibility to backtrack the respondents cluster membership and company's current operations style to validate if the collaboration oriented partners already work in long-term business relationships with different actors or if it is a development goal. Because quantitative methods are unable to capture fully the complexity of the maintenance service value future research should investigate more closely the relationship between current operations and the cluster membership and mind-set towards value creation with more in-depth case studies. In addition it would be interesting to focus future research on improved performance. Does acknowledging comprehensively the value creating elements foster also better performances on the financial 
and operational side of a company? The idea is somewhat supported already in this study, but the sample size inside the clusters is not big enough to verify this also statistically.

This study focused on value creation in maintenance services in the industrial context which is often very case-specific. Therefore it would be interesting in future research to further validate the multidimensional value creation scale in another maintenance service field (e.g. construction) to see what of the value elements are generalizable to also other maintenance services and what are specific to the industrial context. For example will EHSQ, development and reliability of the service partner be as highly valued as in the industry or do some other factors get emphasized even more? Finally, the development of performance measures that support the comprehensive value assessment should receive future research attention. This would support the discussions between the different actors in a maintenance service network and also make the value created and mutual development objectives more concrete.

\section{Conclusions}

This paper contributes to the value creation, and industrial service development literature by providing insight into the value creating elements of maintenance services. This study shows the value of maintenance services as a multidimensional phenomenon where value is captured with different aspects of relationship synergies, reliability of the service partners, development, availability, service solutions and problem solving ability, EHSQ (environment, health, safety and quality) and adaptability to suit different situations. However, what elements are highlighted varies between the actors in the field; some actors are very transaction oriented versus others who are very relational oriented. Therefore, academics and managers should pay attention to the heterogeneity of the actors operating in the field in terms of value creation. Communication and mutual understanding of the value creating strategies is important so that more complete offerings can be built in industrial service networks.

\section{References}

Ahonen, T., Reunanen, M., Pajari, O. and Ojanen, V. (2010), "Maintenance communities - a new model for the networked delivery of maintenance services", International Journal of Business Innovation and Research, Vol. 4, No. 6, pp. 560-583.

Allee, V. (2000), "Reconfiguring the value network", Journal of Business Strategy, Vol. 21, No. 4, pp. 36-39.

Al-Turki, U. (2011), "A framework for strategic planning in maintenance", Journal of Quality in Maintenance Engineering, Vol. 17, No. 2, pp. 150-162.

Al-Sultan, K.S. and Duffuaa, S.O. (1995), "Maintenance control via mathematical programming", Journal of Quality in Maintenance Engineering, Vol. 1 No. 3, pp. 36-46.

Anderson, J.C., Narus, J.A. (1998), "Business marketing: Understand what customers value”, Harvard Business Review, (November-December), pp. 53-65.

Axelsson, B., and Wynstra, F. (2002), "Buying business services", Chichester: John Wiley \& Sons.

Baba, M.L. (1988), "Two sides to every story: An ethnohistorical approach to organizational partnerships", City and Society, Vol. 2, No. 2, pp. 71-104. 
Ballantyne, D. and Varey, R.J. (2006), "Creating value-in-use through marketing interaction: the exchange logic of relating, communicating and knowing", Marketing Theory, Vol. 6 No. 3, pp. 335-348.

Ballantyne, D., Frow, P., Varey, R.J. and, Payne, A. (2011), "Value propositions as communication practice: Taking a wider view", Industrial Marketing Management, Vol. 40, Iss. 2, pp. 202-210.

Barry, J. and Terry, T. (2008), "Empirical study of relationship value in industrial services", Journal of Business \& Industrial Marketing, Vol. 23, No. 4, pp. 228-241.

Bengtsson, M. and Kock, S. (2000), “Coopetion' in business networks - to cooperate and compete simultaneously”, Industrial Marketing Management, Vol. 29, No. 5, pp. 411-426.

Bertolini, M., Bevilacqua, M., Braglia, M. and Frosolini, M. (2004), "An analytical method for maintenance outsourcing service selection", International Journal of Quality \& Reliability Management, Vol. 21 No. 7, pp. 772-88.

Brito, E.P.Z., Beneduzzi, R.L. and Brito, A.L.A.L. (2007), "Customer choice of a car maintenance service provider: A model to identify service attributes that determine choice", International journal of Operations \& Production Management, Vol. 27, Iss. 5, pp. 464-481.

Costello, A.B., and Osborne, J.W. (2005) "Best practices in exploratory factor analysis: Four recommendations for getting the most from your analysis. Practical Assessment”, Research and Evaluation, Vol. 10, pp. 1-9.

Day, G.S. (2000), "Managing market relationships", Journal of the Academy of Marketing Science, Vol. 28, No. 1, pp. 24-30.

EFNMS (2016), "Details of the safety and environment committee" [online] http://www.efnms.org/European-Health-Safety-and-EnvironmentCommittee/m2712/European-Health-Safety-and-Environment-Committee-EHSEC.html (accessed 20 May 2016).

EU-OHS (2012), Procurement of Maintenance Services and Health and Safety at Work, E-fact 63 [online] https://osha.europa.eu/en/publications/e-facts/e-fact-63-procurement-ofmaintenance-services-and-health-and-safety-at-work (accessed 27 June 2013).

Johansson, P. and Olhager, J. (2004), "Industrial service profiling: Matching service offerings and processes", International Journal of Production Economics, Vol. 89, No. 3, pp. 309-320.

Campbell, J.D. (1995),"Outsourcing in maintenance management", Journal of Quality in Maintenance Engineering, Vol. 1, Iss. 3, pp. 18-24.

Grönroos, C. (2011), "Value co-creation in service logic: A critical analysis", Marketing Theory, Vol 11, No. 3, pp. 279-301.

Grönroos, C. and Helle, P. (2010), "Adopting a service logic in manufacturing: Conceptual foundation and metrics for mutual value creation", Journal of Service Management, Vol. 21, No. 5, pp. 564-590.

Grönroos, C. and Ravald, A. (2009), "Marketing and the logic of service: value facilitation, value creation and co-creation and their marketing implications", Working Paper 542, Hanken School of Economics, Helsinki. 
Ali-Marttila, M., Marttonen-Arola, S., Kärri, T., Pekkarinen, O., \& Saunila, M. (2017). Understand what your maintenance service partners value. Journal of quality in maintenance engineering, 23(2), 144-164.

Gupta, S. and Lehmann, D.R. (2005), "Managing Customers as Investments - The strategic value of customers in the long run", Wharton School Publishing, Upper Saddle River, NJ.

Hallikas, J., Immonen, M., Pynnönen, M. and Mikkonen, K. (2014), "Service purchasing and value creation: Towards systemic purchases", International Journal of Production Economics, Vol. 147, pp. 53-61.

Hatinen, L., Pirttilä, M., Viskari, S. and Kärri, T. (2012), "The investment logics of Finnish industrial maintenance service providers", International Journal of Strategic Engineering Asset Management, Vol. 1, No. 1, pp. 33-48.

Kindström, D. and Kowalkowski, C. (2009), "Development of industrial service offerings: a process framework", Journal of Service Management, Vol. 20, No. 2, pp. 156-172.

Kohtamäki, M. and Partanen, J. (2016), "Co-creating value from knowledge-intensive business services in manufacturing firms: The moderating role of relationship learning in suppliercustomer interactions, Journal of Business Research, Vol. 69, Iss. 7, pp. 2498-2506.

Kremic, T., Tukel, O.I. and Walter O.R., (2006),'Outsourcing decision support: a survey of benefits, risks, and decision factors", Supply Chain Management: An International Journal, Vol. 11, Iss. 6, pp. 467-482.

Lambert, D.M. and Enz, M.G. (2012), "Managing and measuring value co-creation in businessto-business relationships", Journal of Marketing Management, Vol. 28, Nos. 13-14, pp. 15881625 .

Lapierre, J. (2000), “Customer-perceived value in industrial contexts”, Journal of Business \& Industrial Marketing, Vol. 15, No. 2, pp. 122-145.

La Rocca, A. and Snehota, I. (2014), "Value creation and organizational practices at firm boundaries, Management Decision, Vol. 52, No. 1, pp. 2-17.

Lind, S., Nenonen, S. and Kivistö-Rahnasto, J. (2008), "Safety risk assessment in industrial maintenance", Journal of Quality in Maintenance Engineering, Vol. 14, No. 2, pp. 205-217.

Lindgreen, A., Hingley, M.K., Grant, D.B. and Morgan, R.E. (2012), "Value in business and industrial marketing: Past, present, and future", Industrial Marketing Management, Vol. 41, Iss. 1, pp. 207-214.

Lindgren, A. and Wynstra, F. (2005), "Value in business markets: what do we know? Where are we going?", Industrial Marketing Management, Vol. 34, No. 7, pp. 732-748.

Liyanage, J.P. and Kumar, U. (2003), "Towards a value-based view on operations and maintenance performance management", Journal of Quality in Maintenance Engineering, Vol. 9, No. 4, pp. 333-350.

Lo, S-H. (2010), "Performance evaluation for sustainable business: a profitability and marketability framework", Corporate Social Responsibility and Environmental Management, Vol. 17, No. 6, pp. 311-319.

Lorenzoni, G. and Lipparini, A. (1999), "The leveraging of interfirm relationships as a distinctive organizational capability: a longitudinal study", Strategic Management Journal, Vol. 20, No. 4, pp. 317-338. 
Ali-Marttila, M., Marttonen-Arola, S., Kärri, T., Pekkarinen, O., \& Saunila, M. (2017). Understand what your maintenance service partners value. Journal of quality in maintenance engineering, 23(2), 144-164.

Ma, Q., Pearson, M.J. and Tadisina, S. (2005), "An exploratory study into factors of service quality for application service providers", Information \& Management, Vol. 42, Iss. 8, pp. 1067-1080.

Malleret, V. (2006), "Value Creation through Service Offers," European Management Journal, Vol. 24, No. 1, pp. 106-116.

Marais, K. and Saleh, J. (2008), "Beyond its cost, the value of maintenance: an analytical framework for capturing its net present value", Journal of Reliability Engineering and System Safety, Vol. 94, No. 2, pp. 644-657.

Matthyssens, P. and Vandenbempt, K. (1998), "Creating competitive advantage in industrial services”, Journal of Business \& Industrial Marketing, Vol. 13, Iss. 4, pp. 339-355.

McDonough, E.F.III, Athanassiou, N. and Barczak, G. (2006), "Networking for global new product innovation", International Journal of Business Innovation and Research, Vol. 1, Nos. 1/2, pp. 9-26.

Murthy, D.N.P, Karim, M.R. and Ahmadi, A. (2015), "Data management in maintenance outsourcing”, Reliability Engineering and System Safety, Vol. 142, pp. 100-110.

Ojanen, V., Ahonen, T., Reunanen, M. and Hanski, J. (2012A), “Towards availability and sustainability in customer value assessment of asset management services", International Journal of Innovation and Sustainable Development, Vol. 6, No. 4, pp. 368-391.

Ojanen, V., Hatinen, L., Kärri, T., Kässi, T. and Tuominen, M. (2012B), "Flexible investment planning and collaborative maintenance management", in van der Lei, T., Herder, P. and Wijnia, Y. (Eds.): Asset Management: The State of the Art in Europe from a Life Cycle Perspective, pp. 65-77, Springer, Dordrecht.

Oliva, R. and Kallenberg, R. (2003), "Managing the transition from products to services", International Journal of Service Industry Management, Vol. 14, No. 2, pp. 160-172.

Panesar, S.S. and Markeset, T. (2008), "Development of a framework for industrial service innovation management and coordination", Journal of Quality in Maintenance Engineering, Vol. 14, No. 2, pp. 177-193.

Parida, A. and Kumar, U. (2006), "Applications and case studies: maintenance performance measurement (MPM): issues and challenges", Journal of Quality in Maintenance Engineering, Vol. 12, No. 3, pp. 239-251.

Penttinen, E. and Palmer, J. (2006), "Improving firm positioning through enhanced offerings and buyer-seller relationships", Industrial Marketing Management, Vol. 36, Iss. 4, pp. 552564.

Persona, A., Regattieri, A., Pham, H. and Battini, D. (2007), "Remote control and maintenance outsourcing networks and its applications in supply chain management", Journal of Operations Management, Vol. 25, Iss. 6, pp. 1275-1291.

Pintelon, L. and Parodi-Herz, A. (2008), Maintenance: An Evolutionary Perspective. Complex System Maintenance Handbook, Springer series in reliability engineering, London: Springer. 
Podsakoff, P.M., MacKenzie, S.B., Lee, J.Y. and Podsakoff, N.P. (2003), "Common method biases in behavioral research: a critical review of the literature and recommended remedies", Journal of Applied Psychology, Vol. 88, No. 5, pp. 879-903.

Ramsey, J. and Wagner, B. (2009), “Organisational Supplying Behaviour: Understanding supplier needs, wants and preferences", Journal of Purchasing \& Supply Management, Vol. 15, Iss. 2, pp. 127-138.

Reinartz, W. and Ulaga, W. (2008), "How to sell services more profitably", Harvard business review, Vol. 86, No. 5, pp. 90-6.

Rekola, K. and Haapio, H. (2009), Industrial Services and Service Contracts: A Proactive Approach, The Federation of Finnish Technology Industries, Helsinki.

Riis, J., Johansen, J., Waehrens, B. and Englyst, L. (2007), "Strategic roles of manufacturing", Journal of Manufacturing Technology Management, Vol. 18, No. 8, pp. 933-948.

Rosqvist, T., Laakso, K. and Reunanen, M. (2009), "Value-driven maintenance planning for a production plant", Reliability Engineering and System Safety, Vol. 94, No. 1, pp. 97-110.

Songailiene, E., Winklhofer, H. and McKechnie, S. (2011), “A conceptualisation of supplierperceived value”, European Journal of Marketing, Vol. 45, Iss. 3, pp. 383-418.

Stremersch, S., Wuyts, S. and Frambach, R.T. (2001), "The purchasing of full-service contracts: an exploratory study within the industrial maintenance market", Industrial Marketing Management, Vol. 30, No. 1, pp.1-12.

Stuart, T.E. (2000), "Interorganizational alliances and the performance of firms: a study of growth and innovation rates in a high-technology industry", Strategic Management Journal, Vol. 21, No. 8, pp.791-811.

The Finnish Maintenance Society (2007), "Maintenance in national economy of Finland", [online] http://www.promaint.net/instancedata/prime_product_yhdistys/kpmedia/embeds/promaintwwwstructure/kunnossapito_2007_180407.pdf (accessed May 20, 2016) (in Finnish).

Toossi, A., Lockett, L., Raja, J.Z. and Martinez, V. (2013), “Assessing the value dimensions of outsourced maintenance services", Journal of Quality in Maintenance Engineering, Vol. 19 No. 4 pp. 348-363.

Tuli, K.R., Kohli, A.K. and Bharadwaj, S.G. (2007), "Rethinking business solutions: from product bundles to relational processes", Journal of Marketing, Vol. 71, No. 3, pp. 1-17.

Ulaga, W. (2003), "Capturing value creation in business relationships: A customer perspective”, Industrial Marketing Management, Vol. 32 No. 8, pp. 677-693.

Vargo, S.L. and Lusch, R.F. (2008), "Service-dominant logic: continuing the evolution", Journal of the Academy of Marketing Science, Vol. 36, No. 1, pp. 1-10. 
Ali-Marttila, M., Marttonen-Arola, S., Kärri, T., Pekkarinen, O., \& Saunila, M. (2017). Understand what your maintenance service partners value. Journal of quality in maintenance engineering, 23(2), 144-164.

\section{Appendix 1}

Descriptive statistics of the clusters

\begin{tabular}{|c|c|c|c|c|c|c|c|c|}
\hline & \multicolumn{2}{|c|}{ All clusters $(n=82)$} & \multicolumn{2}{|c|}{ Cluster $1(\mathrm{n}=28)$} & \multicolumn{2}{|c|}{ Cluster $2(n=20)$} & \multicolumn{2}{|c|}{ Cluster 3(n=34) } \\
\hline & Number & Percentage & Number & Percentage & Number & Percentage & Number & Percentage \\
\hline \multicolumn{9}{|c|}{ Number of employees } \\
\hline under 10 & 7 & $9 \%$ & 4 & $14 \%$ & 1 & $5 \%$ & 2 & $6 \%$ \\
\hline $10-49$ & 19 & $23 \%$ & 6 & $21 \%$ & 3 & $15 \%$ & 10 & $29 \%$ \\
\hline $50-249$ & 24 & $29 \%$ & 10 & $36 \%$ & 4 & $20 \%$ & 10 & $29 \%$ \\
\hline over 250 & 32 & $39 \%$ & 8 & $29 \%$ & 12 & $60 \%$ & 12 & $35 \%$ \\
\hline \multicolumn{9}{|c|}{$\begin{array}{l}\text { Approximate turnover } \\
(€)\end{array}$} \\
\hline $\begin{array}{l}\text { under } \\
\text { 1million }\end{array}$ & 9 & $11 \%$ & 5 & $18 \%$ & 1 & $5 \%$ & 3 & $9 \%$ \\
\hline 1-20 million & 23 & $28 \%$ & 6 & $21 \%$ & 4 & $20 \%$ & 13 & $38 \%$ \\
\hline $\begin{array}{l}21-100 \\
\text { million }\end{array}$ & 20 & $24 \%$ & 8 & $29 \%$ & 5 & $25 \%$ & 7 & $21 \%$ \\
\hline $\begin{array}{l}\text { over } \quad 100 \\
\text { million } \\
\text { Position of the }\end{array}$ & $\begin{array}{l}30 \\
\text { responden }\end{array}$ & $37 \%$ & 9 & $32 \%$ & 10 & $50 \%$ & 11 & $32 \%$ \\
\hline $\begin{array}{l}\text { senior } \\
\text { management }\end{array}$ & 17 & $21 \%$ & 4 & $14 \%$ & 2 & $10 \%$ & 11 & $32 \%$ \\
\hline $\begin{array}{l}\text { middle } \\
\text { management }\end{array}$ & 46 & $56 \%$ & 19 & $68 \%$ & 12 & $60 \%$ & 15 & $44 \%$ \\
\hline other & 19 & $23 \%$ & 5 & $18 \%$ & 6 & $30 \%$ & 8 & $24 \%$ \\
\hline \multicolumn{9}{|c|}{ Organization unit primarily } \\
\hline customer & 31 & $38 \%$ & 5 & $18 \%$ & 9 & $45 \%$ & 17 & $50 \%$ \\
\hline $\begin{array}{l}\text { service } \\
\text { provider }\end{array}$ & 36 & $44 \%$ & 16 & $57 \%$ & 7 & $35 \%$ & 13 & $38 \%$ \\
\hline $\begin{array}{l}\text { equipment } \\
\text { and service } \\
\text { provider }\end{array}$ & 15 & $18 \%$ & 7 & $25 \%$ & 4 & $20 \%$ & 4 & $12 \%$ \\
\hline \multicolumn{9}{|c|}{ Financial performance of unit } \\
\hline bad & 1 & $1 \%$ & 0 & $0 \%$ & 0 & $0 \%$ & 1 & $3 \%$ \\
\hline sufficient & 15 & $19 \%$ & 5 & $19 \%$ & 4 & $21 \%$ & 6 & $18 \%$ \\
\hline good & 45 & $56 \%$ & 12 & $44 \%$ & 11 & $58 \%$ & 22 & $65 \%$ \\
\hline excellent & 19 & $24 \%$ & 10 & $37 \%$ & 4 & $21 \%$ & 5 & $15 \%$ \\
\hline no response & 2 & & & & & & & \\
\hline \multicolumn{9}{|c|}{ Operative performance of unit } \\
\hline bad & 1 & $1 \%$ & 0 & $0 \%$ & 1 & $5 \%$ & 0 & $0 \%$ \\
\hline sufficient & 11 & $14 \%$ & 1 & $4 \%$ & 7 & $37 \%$ & 3 & $9 \%$ \\
\hline good & 54 & $68 \%$ & 19 & $70 \%$ & 9 & $47 \%$ & 26 & $76 \%$ \\
\hline excellent & 14 & $18 \%$ & 7 & $26 \%$ & 2 & $11 \%$ & 5 & $15 \%$ \\
\hline no response & 2 & & & & & & & \\
\hline
\end{tabular}

